\title{
News from the Invisible World: The Publishing History of Tales of the Supernatural c.1660-1832
}

\author{
Jonathan Barry
}

This chapter explores the transmission of tales of the supernatural during the very long eighteenth century (between c.1660 and 1832). When writing my last book, on the transmission of a specific tale of the conjuration of spirits over the same period, I became aware of a genre of publications on this subject which had not been studied. These are anthologies of supposedly true stories, usually relating to named people and places and sometimes dated, often each numbered separately, with relatively little discussion of their authenticity or significance, beyond perhaps a brief preface defending the reality of the world of spirits. ${ }^{1}$ This

${ }^{1}$ Jonathan Barry, Raising Spirits: How a Conjuror's Tale Was Transmitted Across the Enlightenment (Basingstoke, 2013); id., Witchcraft and Demonology in South-West England c.1640-1789 (Basingstoke, 2012), 259-60.

\footnotetext{
J. Barry $(\triangle)$

Department of History, University of Exeter, Exeter, UK e-mail: j.barry@ex.ac.uk

(C) The Author(s) 2018

J. Barry et al. (eds.), Cultures of Witchcraft in Europe from the Middle Ages to the Present, Palgrave Historical Studies in Witchcraft and Magic, https://doi.org/ 10.1007/978-3-319-63784-6_9
} 
distinguishes them (although this is a spectrum rather than an absolute distinction) from other volumes which might contain such stories but integrate them within a more argumentative framework, or from shorter accounts of individual incidents, as well as from a growing genre of overtly fictional stories. Potentially, the analysis of these stories, especially those most commonly cited, could reveal their characteristic motifs and also consider the degree to which this published tradition may have influenced the oral culture of the supernatural, feeding the public with model stories, just as many ballads and fairy tales collected by nineteenth-century folklorists have been shown to be based on printed sources, not on an ancient oral tradition. ${ }^{2}$ However, this preliminary study cannot explore those dimensions because it is necessary first to establish the nature and history of these publications themselves.

Historiographically, these publications have been neglected because they do not fit neatly into a number of related genres, each intensively studied, and fall between the disciplinary interests of historians, literary critics and folklorists. These volumes originate in the spate of controversial works published in the later seventeenth century to demonstrate the reality of spirits against the threat of materialistic atheism. ${ }^{3}$ These works, and their relationship to notions of scientific evidence and natural theology, have been intensively studied, both in relation to the history of witchcraft and the supernatural, ${ }^{4}$ and more generally in terms of evolving

\footnotetext{
${ }^{2}$ Willem de Ble (with an acute accent on it) court, Tales of Magic, Tales in Print: On the Genealogy of Fairy Tales and the Brothers Grimm (Manchester, 2012).

${ }^{3}$ John Newton (ed.), Early Modern Ghosts (Durham, 2002); Jo Bath and John Newton. " "Sensible Proof of Spirits": Ghost Belief During the Later Seventeenth Century', Folklore 117 (2006), 1-14; Sasha Handley, Visions of an Unseen World: Ghost Beliefs and Ghost Stories in Eighteenth-Century England (2007), 26-40; Owen Davies, The Haunted: A Social History of Ghosts (New York, 2007), 8, 101-32; A.J. McKeever 'The Ghost in Early Modern Protestant Culture: Shifting Perceptions of the Afterlife 1450-1700' (University of Sussex PhD thesis, 2010). For the European context see Stuart Clark, Vanities of the Eye (New York and Oxford, 2009), esp. 204-35 and 300-28.

${ }^{4}$ Wallace Notestein, A History of Witchcraft in England from 1558 to 1718 (Washington, DC, 1911); Keith Thomas, Religion and the Decline of Magic (1971); Gillian Bennett, 'Ghost and Witch in the Sixteenth and Seventeenth Centuries', Folklore, 97 (1986), 3-14; James Sharpe, Instruments of Darkness: Witchcraft in England 1550-1750 (1996); Ian Bostridge, Witchcraft and Its Transformations c.1650-1750 (Oxford, 1997); Peter Marshall and Alex Walsham (eds.), Angels in the Early Modern World (Cambridge, 2006); John Newton and Jo Bath (eds.), Witchcraft and the Act of 1604 (Leiden, 2008); Alexandra Walsham, 'The Reformation and the "Disenchantment of the World" Reassessed',
} 
notions of providence and prodigies. ${ }^{5}$ The propaganda role of providentialist accounts, both in religious literature and in the ideological struggles of the civil wars and rage of party, has been well studied, but much less work has been done on such material after the 1720s, except in the specific context of the evangelical revival. Instead, the main focus has been on the 'rise of supernatural fiction', beginning with the role of the supernatural in the foundation of the English novel (notably in Defoe), ${ }^{6}$ and then analysing Gothic fiction and its influence on Romanticism. ${ }^{7}$ Literary critics have explored with great subtlety both the changing 'verisimilitude' sought in such stories and the 'aestheticisation' of the supernatural, with the emphasis shifting from the authenticity of the story to the authenticity of its effects on the reader's feelings, and authors' desire to evoke such feelings to offset the impact (again) of growing materialism and the perceived 'disenchantment of the world'. Although these accounts consider the wider cultural contexts of these developments in fiction, they have not explored the continuing publication of supposedly factual supernatural stories.

Historical Journal, 51 (2008), 497-528; id., 'Invisible Helpers: Angelic Intervention in Post-Reformation England', Past and Present, 208 (August 2010), 78-130; Joel Raymond (ed.), Conversations with Angels (Basingstoke, 2011); Michael Hunter, 'The Decline of Magic', Historical Journal, 55 (2012), 399-425; Peter Elmer, Witchcraft, Witch-hunting, and Politics in Early Modern England (Oxford, 2016).

${ }^{5}$ Malcolm Gaskill, 'The Displacement of Providence', Continuity and Change, 11 (1996), 341-74; Alexandra Walsham, Providence in Early Modern England (Oxford, 1999); William E. Burns, Age of Wonders: Politics, Prodigies and Providence in England 1657-1727 (Manchester, 2002); Vladimir Jankovic, 'The Politics of Sky Battles in Early Hanoverian England', Journal of British Studies, 41 (2002), 429-59; J.C.D. Clark, 'Providentialism, Predestination and Progress', Albion, 35 (2003), 559-89; Peter Marshall, Mother Leakey and the Bishop (Oxford, 2007).

${ }^{6}$ Coleman Parsons, 'Ghost Stories before Defoe', Notes and Queries, 201 (July 1956), 293-8; R. Capoferro, Historicising the Fantastic 1660-1760 (Bern, 2000) and references in nn. 26-7.

${ }^{7}$ Emma Clery, The Rise of Supernatural Fiction, 1762-1800 (Cambridge, 1995); Margaret L. Carter, Specter or Delusion? The Supernatural in Gothic Fiction (Ann Arbor and London, 1987); Terry Castle, The Female Thermometer (New York and Oxford, 1995); Julian Wolfreys, Victorian Hauntings: Spectrality, Gothic, the Uncanny and Literature (Basingstoke, 2002); Franz J. Potter, The History of Gothic Publishing 1800-35 (Basingstoke, 2005); Handley, Visions, 199-208; Shane McCorristine, Spectres of the Self: Thinking about Ghosts and Ghost-Seeing in England (Cambridge, 2010). 
Similarly, the revived interest of historians in supernatural beliefs after 1720 has tended to ignore these works. Owen Davies has recovered the history of 'grimoires' as part of his work on magical practitioners and their clients, while Paul Monod and others have explored an 'occult enlightenment' of those who used magical texts. ${ }^{8}$ This influenced the publications I am studying, but these works gave no practical details about the nature and practice of magic, nor, by and large, do they throw any light on how ordinary people thought or felt about magic. Their protagonists were largely members of the middling and upper classes based in urban settings, and the supernatural occurrences they report happened to them uninvited, not because they were seeking magical assistance. There are almost no accounts involving witches, cunning folk or use of magic except in witchcraft stories reprinted from the pre1720 period. For this reason they bear little relation to the kinds of stories which nineteenth-century folklorists sought to elicit from ordinary rural people, nor have modern historians of popular supernaturalism paid them any attention. ${ }^{9}$

Nevertheless, these various historiographies raise important issues for analysing the characteristic themes and tensions contained within the publications to be considered here. These works almost all appeal, with varying levels of intensity and conviction, to the need to defend belief in a providential God and a world of spirits against a growing materialist scepticism. They also struggle with the question of how to authenticate

\footnotetext{
${ }^{8}$ Owen Davies, Witchcraft, Magic and Culture 1736-1951 (Manchester, 1999); id., Cunning Folk (2003); id., Grimoires (Oxford, 2009); id., and Willem de Blécourt (eds.), Beyond the Witch Trials: Witchcraft and Magic in Enlightenment Europe (Manchester, 2004); Paul Monod, Solomon's Secret Arts: The Occult in the Age of the Enlightenment (New Haven and London, 2013). For the nineteenth century see Nicola Bown et al. (eds.), The Victorian Supernatural (Cambridge, 2004); Antonio Melechi, Servants of the Supernatural (2008); Shane McCorristine (ed.), Spiritualism, Mesmerism and the Occult, 1800-1920 5 volumes (2012), esp. vol. 1 'Apparitions, Spectral Illusions, and Hallucinations'; Tatiana Kontou and Sarah Wilburn (eds.), The Ashgate Research Companion to Nineteenth-Century Spiritualism and the Occult (2012); Gavin Budge, Romanticism, Medicine and the Natural Supernatural: Transcendent Vision and Bodily Spectres 1789-1852 (Basingstoke, 2012).

${ }^{9}$ Owen Davies, 'Newspapers and Popular Belief in Witchcraft and Magic', Journal of British Studies, 37 (1998), 139-65; id., A People Bewitched: Witchcraft and Magic in Nineteenth-Century Somerset (Bruton, 1999); Karl Bell, The Magical Imagination: Magic and Modernity in Urban England (Cambridge, 2012); Thomas Waters, "They seem to have all died out": Witches and Witchcraft in Lark Rise to Candleford and the English Countryside, c.1830-1930', Historical Research, 87 (2014), 134-53.
} 
their stories, a problem inherent in the genre itself, and especially in reproducing a battery of short accounts (except in so far as their sheer number implies the truth of at least some of them). Did the authenticity lie in the source of the information, and was that the credibility of the original witnesses or of the authors from whom the stories were recycled (and should authors be identified - a potential publishing problem if this revealed to potential readers that the collection contained nothing new!)? Or did the authenticity depend on the verisimilitude of the narrative itself and, if so, what did that consist of - was it sufficient detail of circumstances, such as people and setting, or was it the precise recording of the supernatural occurrence itself? To what extent was it legitimate to increase verisimilitude by deploying 'novelistic' devices of, for example, dialogue or consideration of character and motive, or would these mark a fictionalisation which would weaken the report's credibility? More generally, was the intended audience one of sceptics to be won over or of existing believers who wished to have their beliefs confirmed, or was it perhaps a group lying between, inclined in principle to believe but sceptical about any specific story? Were the stories intended to furnish material for private deliberation or for communal discussion, perhaps at the tavern or round the family table or fireside? If so, what was the relationship between these published accounts and the often-derided culture of 'chimney-side' stories told (stereotypically) by old women and peasants?

The final context to be mentioned is that of the history of the book and reading, which has again become immensely productive, assisted by developments in cataloguing and digital reproduction. Perhaps the most fruitful (if controversial) contribution has been William St Clair's argument that the economics of the trade promoted a stark divide between relatively expensive new publications which reflected the Enlightenment and the recycling of a pre-Enlightenment set of texts and attitudes in cheap publications. This study will give some support to that view (noting the long publication history of some seventeenth-century texts, notably Sinclair, and the recycling of others) but also indicate (as his critics have suggested) that St Clair's account neglects important new formats, notably newspapers and periodicals, through which new materials reached broad readerships. ${ }^{10}$ Both evangelical and commercial

\footnotetext{
${ }^{10}$ William St Clair, The Reading Nation in the Romantic Period (Cambridge, 2004) and T. Bonnell's review in Studies in Bibliography, 57 (2005-6), 243-61; John Barnard and D.
} 
periodicals generated numerous new reports of supernatural events which, from about the 1770s, began to complement, and sometimes replace, the older materials in these books, in some cases mixed in with fictionalised stories. The same period also saw the appearance of sceptical publications designed to persuade the public (specifically children and others seen as prone to 'superstition') not to believe these stories: I will not be considering this genre in depth except for noting which publications and stories sceptics considered they most needed to counter.

\section{$1650-1705$}

It was generally agreed until 1832, by sceptics and believers alike, that the core texts of supernatural experiences current were those published between 1650 and 1705. The most influential was Saducismus Triumphatus (1681) by Joseph Glanvill and Henry More (often known simply as 'Glanvill on witches') with other works by Thomas Bromhall, Richard Bovet, George Sinclair, Richard Baxter, Nathaniel Crouch, John Aubrey and John Beaumont. (One might also add Increase and Cotton Mather in New England, but there is not space to discuss them here. ${ }^{11}$ )

Interestingly, their influence was not accompanied, except in one case, by frequent reprintings. Saducismus went through three editions with its original publishers by 1700, and Crouch published three editions of his The Kingdom of Darkness (1688) by 1705, but there were no second editions of Bromhall's Treatise of Specters or an History of Apparitions (1658), Bovet's Pandaemonium (1684), Baxter's Certainty of the World of Spirits (1691, often referenced by its running head 'Historical Discourse of Apparitions and Witches'), Turner's Compleat History of the Most Remarkable Providences (1697) or Beaumont's

F. McKenzie (eds.), The Cambridge History of the Book in Britain. Volume 4, 1557-1695 (Cambridge, 2002); Michael F. Suarez and Michael L. Turner (eds.), The Cambridge History of the Book in Britain. Volume 5, 1695-1830 (Cambridge, 2009); James Raven, The Business of Books (Yale, 2007).

${ }^{11}$ See M.P. Winship, Seers of God: Puritan Providentialism in the Restoration and Early Enlightenment (Baltimore, 1996). 
Treatise of Spirits (1705). ${ }^{12}$ Then between 1721 and 1728 two London publishers, Arthur Bettesworth and Jeremiah Batley, produced new editions of Aubrey's Miscellanies of 1696 (1721, with an account of his life), Saducismus (1726, with an account of Glanvill's works) and finally Crouch (1728); they also republished many of Crouch's other collections, including Wonderful Prodigies of Judgement and Mercy (1682; '8th edition' 1729), which included similar material. ${ }^{13}$ Retailing at $4 \mathrm{~s}$ and 6s respectively, the editions of Aubrey and Saducismus were not aimed at lower-class readers (who were unlikely to afford anything more than a shilling at most), although their (unpriced) edition of Crouch probably was. Bettesworth (active 1699-1739d at the Red Lion on London Bridge then Paternoster Row) was a leading London bookseller with over a thousand publications and active in several of the 'congers' that combined for major publishing ventures, and Batley (active 1717-1737d at the Dove in Paternoster Row), though slightly less established, was also involved in hundreds of publications, including numerous serial publications, so both men were very experienced at judging the market for substantial works. ${ }^{14}$ This may have led Daniel Defoe to spot a market for his Essay on the History and Reality of Apparitions (1727), discussed in what follows, but if so his success seems to have closed off the market for full reprints of the earlier works (though not, as we shall see, their reuse under other titles). Between 1728 and 1840, the only works except Sinclair to be reprinted were Aubrey in 1784 (possibly for its Wiltshire focus, as a Salisbury bookseller was co-publisher) and Baxter in 1834 (and again in 1840 and 1841) in a joint edition with Cotton Mather's Wonders of the Invisible World (1693). By contrast, George Sinclair's Satan's Invisible World Discovered (Edinburgh, 1685) became a Scottish staple, with editions of the full text (with later additions on

\footnotetext{
${ }^{12}$ Several works attracted continental translations: Saducismus Triumphatus into German at Hamburg in 1701, Beaumont's Treatise into German at Halle in 1721, and Turner's Compleat History into Dutch at Rotterdam in 1737 (republished in 1770 at Utrecht).

${ }^{13}$ Chapter 2 of Wonderful Prodigies was entitled 'The Miserable Endings of Magicians, Conjurors and Witches, with an Account of Apparitions, Possessions and Other Strange and Wonderful Feats and Illusions of the Devil'.

${ }^{14}$ Henry Plomer, Dictionary of Booksellers and Printers 1668-1725 (1922), 26, 34; Raven, Business, 173 and 191 (and 168-83 on the Paternoster Row publishers and their role in the growth of periodicals and broadening the book trade); A Catalogue of Books Printed for and Sold by A. Bettesworth (1728).
} 
the post-1685 Scottish witch trials) published in Edinburgh in 1709, $1746,1769,1779,1780,1789$ and 1808, and in London in 1814, as well as an abbreviated chapbook selection from Stirling in 1807 and at least three Glasgow chapbooks between 1830 and 1840. Sinclair's editor in 1871 noted that the book was 'long a favourite with the labouring classes' and 'for a long time a constituent part of every cottage library in Scotland'-which can hardly have been true of any of the English publications. ${ }^{15}$

Studies of these late-seventeenth-century publications have tended to assimilate all these authors to the model of Glanvill and More, with their clerical focus on combatting atheism and materialism, shared by their correspondent Richard Baxter (and the Mathers), and their concern to document the evidence carefully to convince doubters. ${ }^{16}$ As I have argued elsewhere, this underestimates both the ideological diversity within this group of authors and their varying motives for publication. The radical anti-papist Bovet, the Scottish Presbyterian natural

\footnotetext{
${ }^{15}$ George Sinclair, Secrets of the Invisible World Discovered, edited by T.G. Stevenson (Edinburgh, 1871), preface xlii-xlv; ibid., edited by Coleman Parsons (Gainesville, Florida, 1969); Paul Wood, 'George Sinclair d. 1696' in A. Pyle (ed.), Dictionary of British Seventeenth-Century Philosophers 2 vols. (Bristol, 2000), II: 750-1; John Anderson, 'Sinclair, George (d.1696?)', rev. Anita McConnell, Oxford Dictionary of National Biography, 25615; A. Roffe, 'Intellectual Change before the Enlightenment: Scotland, the Netherlands and the Reception of Cartesian Thought 1650-1700', Scottish Historical Review, 94 (2015), 24-47. For the Scottish context see Peter Maxwell-Stuart, 'Witchcraft and Magic in Eighteenth-Century Scotland' in Davies and de Blécourt (eds.), Beyond, 81-99; Colin Kidd, 'The Scottish Enlightenment and the Supernatural', in Lizanne Henderson (ed.), Fantastical Imaginations (Edinburgh, 2009), 91-109; Lizanne Henderson, Witchcraft and Folk Belief in the Age of Enlightenment: Scotland 1670-1740 (Basingstoke, 2016).

${ }^{16}$ See references in n. 3; Joseph Glanvill, Saducismus Triumphatus, edited by Coleman Parsons (Gainsville, Florida, 1966); Henry More, An Antidote against Atheisme (1653); id., A Collection of Several Philosophical Writings of Dr Henry More (1712[-13]); Alison Coudert, 'Henry More and Witchcraft' in Sarah Hutton (ed.), Henry More (1990), 115-36; Simon Schaffer, 'Godly Men and Mechanical Philosophers: Souls and Spirits in Restoration Natural Philosophy', Science in Context, 1 (1987), 55-85; Michael Hunter, 'New Light on the "Drummer of Tedworth", Historical Research, 78:201 (2005), 311-53; L. Carter, 'A Constant Prodigy: Empirical Views of an Unordinary Nature', The Seventeenth Century, 23 (2008), 265-89; Capoferro, Historicising, 103; Barry, Witchcraft, 14-57, 259-60.
} 
philosopher Sinclair, the hermetically inclined gentleman Aubrey ${ }^{17}$ and the Roman Catholic hermeticist Beaumont all had rather different priorities in telling such stories from the clerical writers, and only Sinclair showed a similar interest in authentication. Furthermore, both Bovet ${ }^{18}$ and Beaumont ${ }^{19}$ (who drew heavily on Baxter, Mather and Aubrey) arguably included such stories largely to make their books more publishable despite the controversial nature of their core message. Publishing priorities probably also drove Bromhall and Turner. As Pierre Kapitaniak has recently identified, Bromhall's book is an unacknowledged translation of two late-sixteenth-century works, one German and one French, with no new content whatsoever (the latest story is a 1579 one from Bodin). ${ }^{20}$ Turner, although apparently in the More/Glanvill/Baxter mould (as a low church Sussex clergyman claiming to be completing a project of collecting providences shared by Presbyterians and Anglicans), was arguably the frontman for a highly miscellaneous publication directed by its publisher John Dunton, largely comprising recycled material from other Dunton titles (as well as from the earlier publications discussed here and the Lives published by the Nonconformist minister Samuel Clarke). Although Dunton, in seeking advance subscriptions for the book, had urged readers to send in their own reports of providential events, very few are actually included, there is little focus on authentication, and the book might be better described as a printed commonplace book of anecdotes and quotations to furnish clergy with illustrations for their sermons. Dunton (while sharing the same

\footnotetext{
${ }^{17}$ See John Aubrey, Three Prose Works, edited by John Buchanan-Brown (Fontwell, 1972); Michael Hunter, The Occult Laboratory (Woodbridge, 2001); Alexandra Walsham, 'Recording Superstition in Early Modern Britain', Past and Present, 199 suppl. 3 (2008), 178-206.

${ }^{18}$ Richard Bovet, Pandaemonium, or the Devil's Cloyster, edited by Montague Summers (Aldington, Kent, 1951); Barry, Witchcraft, 103-23.

${ }^{19}$ Michael Hunter, Magic and Mental Disorder: Sir Hans Sloane's Memoir of John Beaumont (2011); Barry, Witchcraft, 124-64.

${ }^{20}$ Pierre Kapitaniak, 'Thomas Bromhall et la circulation des histoires de fantomes travers l'Europe du XVIIe siécle' Revue d'Histoire Moderne et Contemporaine (forthcoming). Bath and Newton, "'Sensible Proof"', 4, and McKeever 'Ghost', 203-8 both discuss Bromhall's unusual features without realising it is a translation. Bromhall's publisher, John Streater, was publishing numerous works of Paracelsian or Hartlibian natural philosophy in this period: see Adrian Johns, The Nature of the Book (Chicago and London, 1998), 287-8.
} 
Presbyterian providentialism) was an entrepreneur exploiting public interest in the spirit world, as he showed in his Athenian Mercury and in his publication (never completed) of the English translation of the radically anti-providentialist Balthasar Bekker's The World Bewitched (1694).21 Even more naked commercialism inspired the bookseller Nathaniel Crouch (writing as 'R.B.' or 'R. Burton'), who pioneered a new format of one-shilling volumes in which he brought together, at a price and in a style familiar to chapbook readers (complete with woodcuts, often of no relevance to the story), all the most entertaining, as well as instructive, anecdotes he could collect. Crouch constructed his justificatory preface and conclusions by plagiarising from More and the Mathers, while the book comprised stories from Bromhall, More/ Glanvill, Increase Mather, Bovet, Sinclair, Samuel Clarke and a number of witchcraft pamphlets. ${ }^{22}$ Between them Crouch and Dunton anticipated most of the techniques (anthologising, abridging, using subscriptions and part numbers) which the eighteenth-century press would use to reach a middling- and lower-class audience.

\section{$1706-1749$}

Dunton's techniques can be seen in the next compilation, Nocturnal Revels or a General History of Dreams, published by Andrew Bell at the Cross Keys and Bible in Cornhill in 1706. Bell (a Scotsman active 1693-1720) had bought from Dunton the right to continue his Athenian Oracle; one of his other publications in 1706 was the first

${ }^{21}$ Turner: Winship, Seers, 59-63, 68-9, 183 n. 66; Burns, Age, 15-19, 132-7; Helen Berry, 'Turner, William (1652/3-1701)', Oxford Dictionary of National Biography, 27875; F.A. van Lieburg, 'Remarkable Providences: the Dutch Reception of an English Collection of Protestant Wonder Stories', in A.J. Gelderblom et al. (eds.) The Low Countries as a Crossroads of Religious Beliefs (Leiden, 2004), 197-219; Handley, Visions, 27-8. On Dunton: Helen Berry, Gender, Society and Print Culture in Late Stuart England (Aldershot, 2003); Handley, Visions, 41-4; Marshall, Mother Leakey, 182-9; A. Fix, 'What Happened to Balthazar Bekker in England? A Mystery in the History of Publishing', Church History and Religious Culture, 90 (2010), 609-31.

${ }^{22}$ R. Mayer, 'Nathaniel Crouch, Bookseller and Historian' Eighteenth-Century Studies, 27 (1994), 391-419; id., History and the Early English Novel (Cambridge, 2004), 12836; Burns, Age, 129-32; Jason McElligott, 'Crouch, Nathaniel [Robert Burton] (c.16401725?)', Oxford Dictionary of National Biography, 52645; Capoferro, Historicising, 115-20. 
English translation (in four volumes) of the Arabian Nights from the 1705 French edition. ${ }^{23}$ Nocturnal Revels is normally catalogued as a version of Thomas Tryon's A Treatise of Dreams and Visions (1689), but although it uses parts of Tryon's introduction, it omits most of his text and adds a second section on dream interpretation 'to make it a universal dreambook' and about ninety pages of 'examples of dreams, both divine and humane, ancient and modern, that have been remarkably accomplish'd'. ${ }^{24}$ The volume in this new form was reprinted in 1749 , 1750, 1767 and 1789 in London, as well as twice in the American colonies, with the 1789 title page describing the story selection as 'historical narratives of apparitions and remarkable providences from scripture and history'. Largely identical to the 1706 edition, the 1789 edition published by James Barker in Russell Court, Drury Lane (which cost 3 s) notes (128) that one can see witches' confessions in Glanvill's Saducismus, the 'Historical Discourse of Apparitions and Witches' (i.e. Baxter) or Turner's History of Remarkable Providences. Finally there is an undated early nineteenth-century edition (at 3s 6d), also by Barker, which adds at the end 'the Singular Dream of Mrs Lee' dated 27 December 1803, cashing in on a sensational 1804 trial.

This aside, there are no other examples I can find of such anthologies published before 1750, ${ }^{25}$ except for the problematic case of Daniel Defoe's An Essay on the History and Reality of Apparitions (1727). The case is problematic partly because Defoe's book (published anonymously, then from 1729 as by 'Andrew Moreton') only introduces stories as part of his argument (despite the title-page claim to 'a great variety of surprizing and diverting examples, never publish'd before'). In almost all cases

${ }^{23}$ J. Dunton, Life and Errors (1705), 206.

${ }^{24}$ For dream books see Daniel Pick and Lyndal Roper (eds.), Dreams and History (2004); Katharine Hodgkin et al. (eds.), Reading the Early Modern Dream: The Terrors of the Night (2008); Ann Marie Plane and Leslie Tuttle (eds.), Dreams, Dreamers, and Visions: The Early Modern Atlantic World (Philadelphia, 2013); Janine Riviere 'Dreams in Early Modern England: Frameworks of Interpretation' (University of Toronto PhD thesis, 2013).

${ }^{25}$ One might regard R. Boulton, A Compleat History of Magick, Sorcery and Witchcraft 2 vols. (1715-16) as an anthology, as, after a justificatory preface, it reproduces, without comment, witchcraft cases from contemporary pamphlets, notably those of 1618, 1664 and 1682, plus Salem and various Scottish trials, although it avoids all the cases reproduced in Saducismus. But it limits itself to witchcraft trials except for the warnings of the death of Buckingham and Lee's letter to Fowler at the end of the first volume (263-73). 
he gives no names (though occasionally initials), precise places or dates, and indeed is often equivocal about whether the story is authentic or merely exemplary, though he plays with conventions of authentication. He rarely draws on the earlier literature (e.g. quoting once from Aubrey on Cashio Burroughs (93-4)), and when he does so it is to be critical of their standards of authentication, noting the contradictions (283-8) between the Aubrey and Clarendon versions of Sir George Villiers' supposed warnings about the death of his son the Duke of Buckingham in 1628 and criticising Glanvill and Aubrey for publishing the story of $\mathrm{Dr}$ Turberville's sister 'without some just inquiries to reconcile it to common sense' (290-1). Only two stories stand out for being told at length with authenticating detail. The first is that of the passage of Captain Thomas Rogers of the Society from London to Virginia in 1694, in which he is saved from shipwreck by a warning, which Defoe claims he got from the captain himself (213-16), and the second is the story of 'the late Reverend Dr Scot', 'never yet published in print' (although he notes a variant at one point!), which is given an engraving (294-306). ${ }^{26}$ The Scott story illustrates a key feature of Defoe's versions, which is that they are rendered in great detail, with dialogue and character description, all in Defoe's flowing style. In these techniques they resemble the version of the apparition of Mrs Veal usually attributed to Defoe, which became the most famous eighteenth-century apparition story (but is not repeated in $A n$ Essay), which critics (both sceptics and believers in the Veal story) claimed was less an authentic factual account than a novelistic rendering. Finally, Defoe is not only very equivocal about the evidence for (and interpretation of) apparitions throughout the book but ends with a series of chapters which debunk false stories, as the result of popish priestcraft,

\footnotetext{
${ }^{26}$ This must refer to Dr John Scott (1638/9-1695), who made clear his belief in the possibility of sensual people haunting churchyards after death in his Of the Christian Life: see The Works of the Reverend and Learned John Scott D.D. sometime Rector of St Giles in the Fields 2 vols. (1718), I: 28, 693-4; Richard J. Ginn, 'Scott, John (1638/9-1695)', Oxford Dictionary of National Biography, 24889. This identification has eluded the otherwise exemplary tracing of Defoe's sources in R.M. Baine, 'Daniel Defoe and the History and Reality of Apparitions', Proceedings of the American Philosophical Society, 106 (1962), $335-47$.
} 
schoolboy pranks or criminal plots, leaving the reader primed to doubt the authenticity of any such stories. ${ }^{27}$

It is, therefore, hard to be sure how readers were meant to react, or would have reacted, to Defoe's book. However, it appears that publishers wished to encourage readers to see it as a collection of stories. After one further edition in 1728 under its original title, the work reappeared in 1729 as The Secrets of the Invisible World Disclos'd or a Universal History of Apparitions (costing 5s) with a contents summary on the title page including 'a collection of the most authentic relations of apparitions, especially that surprizing one attested by the learned Dr Scott', and this title went through further editions in 1735, 1738 and 1740 (4s 6d), then again (with 'Disclos'd' replaced by 'Laid Open') in 1770 . This final edition gave no author's name, claimed to be 'printed for the author' and added to the title page 'likewise Mrs Veal's appearance to Mrs Bargrave, Sir George Villiers to the Duke of Buckingham etc', interpolating within the book (20-32) a version of the Veal/Bargrave story, while abridging some of Defoe's other text. Gradually 'Moreton', as it became known, had been assimilated as a collection of stories.

Defoe's book underwent an even more dramatic fate in 1752, when an unnamed London publisher issued (for 5 s neatly bound), $A$ View of the Invisible World or General History of Apparitions, which was then reprinted in Manchester in 1754, as A General History of Apparritions [sic]. A View is regarded by the ESTC (English Short-Title Catalogue) and ECCO (Eighteenth-Century Collections Online) as being a version of An Essay, and so by Defoe, but this is not the case. ${ }^{28}$ The majority of the volume is indeed drawn from Defoe's book, as his cases, starting with Dr Scott, have been extracted and presented as a series of stories, occupying pages 59-267 and 284 to the end. However, the first 58 pages and pages 267-84 are not from Defoe, but from Glanvill, Beaumont and Fair Warnings to a Careless World (1707), a providentialist collection by Josiah Woodward, the clergyman who pioneered the Reformation of Manners movement and published numerous tracts

\footnotetext{
${ }^{27}$ M.E. Novak, 'Defoe, the Occult, and the Deist Offensive during the Reign of George I', in J. Lemay (ed.), Deism, Masonry and the Enlightenment (Newark, NJ, London and Toronto, 1987), 93-108; Handley, Visions, 80-107; Capoferro, Historicising, 129-36.

${ }^{28}$ As Baine, 'Daniel Defoe', 335 identified.
} 
seeking to reform popular behaviour. ${ }^{29}$ The introduction is not from Defoe, but a standard (if rather lukewarm) defence of the reality of apparitions, ending by quoting Addison on the moral value of such testimonies. The only sign of Defoe's equivocal attitudes is in a long footnote (running across 306-12) which expresses great scepticism about the reliability of apparition stories, ending with the story of 'a very pious but credulous bishop of our Church' who was 'relating a strange story of a Daemon that haunted a girl in Lothbury to a company of gentlemen in the City'. ${ }^{30}$ One of them then tells the story of how, as he was reading in bed, his room was entered by a tall, thin figure with a long sooty garment, holding a tall black staff and a round body of pale light, who led him down the stairs and left, making 'a hideous noise in the street'. When the bishop eagerly asks 'what it might particularly seek', he replies, 'Yes my Lord it was the watchman, who came to shew me that my servants had left all the doors open.'

The long sceptical footnote is a copy of an article, 'Of Ghosts and Apparitions', which appeared in the London Magazine for November 1749 (18: 513-15), which was itself a substantially rewritten version of the chapters 'of ghosts and apparitions' (78-88) in The Humourist (1720) by Thomas Gordon, the anti-clerical independent Whig responsible, with John Trenchard, for a series of radical critiques of the establishment in the period 1719-23. ${ }^{31}$ Gordon's chapters end (88) with the bishop story, which is copied verbatim in the London Magazine and $A$ View. ${ }^{32}$ It probably refers to Edward Fowler (1631/2-1714),

\footnotetext{
${ }^{29}$ John Spurr, 'Woodward, Josiah (1657-1712)', Oxford Dictionary of National Biography, 55600.

${ }^{30}$ The only well-known demonic case involving a maid from Lothbury in London was the possession of Rachel Pindar in 1574, but if a bishop was citing this case he should surely have been aware that, led by Archbishop Parker, the authorities had forced nine-year-old Pindar to confess that the affair was a fraud (or perhaps that was part of the joke against him!): see Katherine Sands, Demon Possession in Elizabethan England (Westport CT, 2004), 75-91.

${ }^{31}$ Leslie Stephen, 'Gordon, Thomas (d. 1750)', rev. Emma Major, Oxford Dictionary of National Biography, 11083.

${ }^{32}$ It is also inserted in two 1728 publications. The first is A View of London and Westminster or the Town Spy where it illustrates the claim that the people of St Margaret's Lothbury 'place a strong belief in apparitions and witches' (51-2), the second in the third and fourth editions only of [Erasmus Jones], A Trip through London (1728, also published by Roberts), most incongruously claiming that the bishop was discussing a demon whose appearance a girl had faked to cover a fight between her three aristocratic lovers (22-3).
} 
bishop of Gloucester, a very keen providentialist and supporter of the Reformation of Manners (who supplied Beaumont (398-400) with the account of Sir Charles Lee, which became a standard tale). ${ }^{33}$ A variant of the story is then included in a satirical volume, Round about our Coal Fire or Christmas Entertainment (undated, but probably 1731-2 judging by the other books advertised in the volume), which was published for one shilling by ' $J$. Roberts in Warwick Lane and sold by the booksellers of town and country'. (The 1734 fourth edition of the work, reprinted in 1796, is notable for the first appearance in print of a version of Jack and the Beanstalk. ${ }^{34}$ ) Roberts was the original publisher of Defoe's Essay (though not later editions/versions) and of many other substantial volumes (including Beaumont's later works), but at 59 pages, with a cover woodcut, this particular work is clearly aimed at a wide market seeking humour, not stories of spirits. ${ }^{35}$ The putative author 'Dick Merryman' offers a satirical dedication to the Covent Garden impresario 'Mr Lun'36 as 'complete witchmaker of England and conjurer general of the universe', who (he claims) has introduced the world to much

${ }^{33}$ Handley, Visions, 29-30, 128; Peter Marshall, 'Ann Jeffries and the Fairies', in Angela McShane and Garthene Walker (eds.), The Extraordinary and the Everyday in Early Modern England (2010), 127-41; Barry, Raising Spirits, 28-31.

${ }^{34}$ The story of Jack the giant-killer is first recorded in 1708 and by 1730 was familiar enough to readers that a Haymarket farce (published by Roberts) about Reason defeating the giants of folly and superstition could name its hero 'Jack': see Jack the Gyant-Killer: A Comi-Tragical Farce of One Act (1730). The 1734 version adds the 'magic beans' aspect, but otherwise is a riotous and bawdy satire on all aspects of 'enchantment', concluding that 'enchantment proceeds from nothing but the chit-chat of an old nurse, or the maggots in a madman's brain' (48). While giant-killing Jack was reprinted regularly in the eighteenth century, the next recorded version of the beanstalk story, in the familiar children's tale, was not published until 1807. See Caroline Goldberg, 'The Composition of "Jack and the Beanstalk"', Marvels and Tales, 15:1 (2001), 11-26; Thomas Green, 'Tom Thumb and Jack the Giant-Killer: Two Arthurian Fairytales?', Folklore, 118 (2007), 123-40; Caitlin R. Green, 'The Arthuriad: One' at www.arthuriana.co.uk/arthuriad/Arthuriad_VolOne.pdf.

${ }^{35}$ For Roberts' role as the leading 'trade publisher' distributing but not financing thousands of publications, mostly at one shilling or less, between 1713 and 1754 see Michael Treadwell, 'London Trade Publishers 1675-1750', Library, 6th ser. 4 (1982), 99-134 at 106-10, 117, 122.

${ }^{36}$ The stage name of John Rich, famous for his Harlequin necromancers, magicians and sorcerers-see Phyllis T. Dircks, 'Rich, John (1692-1761)', Oxford Dictionary of National Biography, 23486. 
more 'agreeable devils and witches' (on stage) than 'Glanvill on witches'. The book then offers a series of mock tales of witches, goblins, spectres, fairies and so forth, in which every tale is driven by sexual misbehaviour disguised as the supernatural. Referring to 'Dr Glanville's great book of ghosts and apparitions' he notes 'the Doctor's book indeed is too highpriced for everyone to purchase' and seeing a ghost in the playhouse would cost as much as the book. 'Nor must you expect a ghost to appear gratis in Hand-Alley, as it did seven years ago (as thousands can testify) for that was laid for ninety-nine years in the Red Sea by the Reverend Mr M- and the learned Dr H-' (36-7). ${ }^{37}$ The book ends with 'another story of a ghost and how much it concern'd a Bishop', linked to the woodcut at the start of the chapter on 'spectres, ghosts and apparitions' $(34,39-40)$. This tells the same watchman anecdote (though in different words), but this time with 'Dr Glanvill famous for a book of witchcraft and apparitions' as the credulous one and the bishop as the sceptic. Referring to the woodcut (Fig. 1) it notes 'so in the picture harlequin lights in the ghost, for how the devil do you think a ghost can be in the dark, and if the devil should stand by his lord's bed it is because he had said "Get thee behind me Satan" or "Avoid me Satan". And therefore I suppose the engraver only made the devil peeping out behind the bed.' 38

A more sober version of the same sceptical message was offered by the untitled lead article in the Universal Spectator for 7 October 1732 (no. 209), reprinted in both the Gentleman's Magazine (as 'of ghosts, daemons and spectres', 1001-2) and the London Magazine (as 'of spectres and apparitions' 333-6) for October 1732. The article 'from my

\footnotetext{
${ }^{37}$ Presumably (despite the claimed date) this is the episode described in the one-page broadsheet $A$ Farther and more Particular Account of a most Strange and Terrible Ghost or Apparition of a Gentlewoman that Appeareth both Night and Day at Mr Jennings's, in Hand-Alley, in Holborn ... Also how several other people set up to watch, among whom were six ministers sent by the Bishop of London. With the prayer which the ministers us'd when they set up to watch (1716). This does not name the ministers involved. A pamphlet, A True Relation of the Apparition that Appeared at Mr Jennings's House (1717), mentions 'two reverend divines' staying in the house to observe the apparition, but does not name them or refer to any prayers (12).

${ }^{38}$ The 'harlequin' reference may suggest this is based on Rich's harlequin performances. I cannot identify any previous use of this woodcut, but it satirises a standard ghost woodcut showing a frightened subject in bed and a ghost with a torch approaching, sometimes with a devil nearby. For an example see plate 9 in C. Marsh, 'Best-selling Ballads and their Pictures in Seventeenth-Century England', Past and Present, 233 (2016), 53-99.
} 
(49)

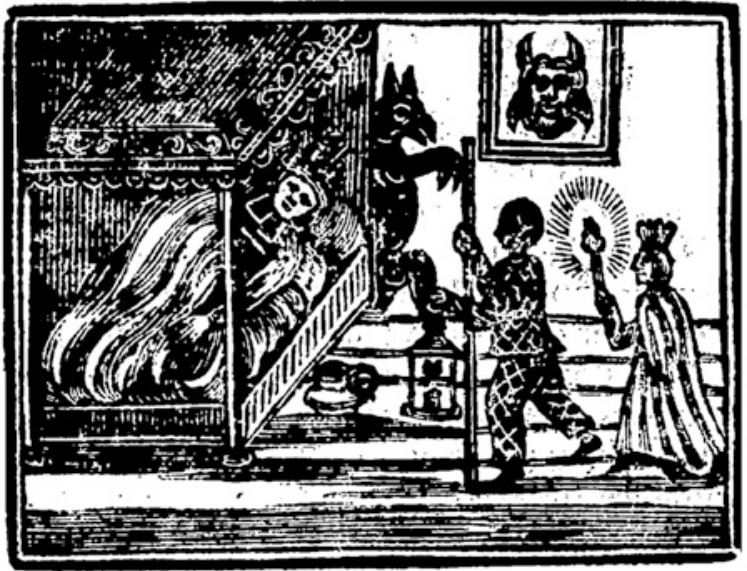

\section{H A P. V.}

Of Spectres, Gbofts, and Apparitions; the great Conveniencies arifing from tbem; and bow to make them.

THEN the Men and the Maids have ended their Gambols, are all feated about the Fire, and Bed-time is drawing on, then Fobn begins fome difmal Story. to the Company about Apparitions and Hobgoblins, and to about it goes'till all the reft of the Society are drawn into the fane kind of Difcourfe, and firighten'd out of their Wits with dreadful Apprehenfions: A Moufe cannot itir, but $N a n$ crecps clofe to Fobn; Sue hugs Tom, and none dare lic alone; then Love and the Devil couples them together, and each one has a Mate for that Night; and when the Thing is once done, there is very little CereHI mony

Fig. 1 Woodcut from Round about our Coal Fire or Christmas Entertainment (London: J. Roberts, undated, but probably 1731-2), 34. [Barry at n. 37] 
house in the Minories' is by the paper's editor, Henry Baker, under his assumed name of 'Henry Stonecastle of Northumberland'. Baker was a natural philosopher, poet, teacher of the deaf and, perhaps most significantly, Defoe's son-in-law since $1729 .{ }^{39}$ He blames spirits and ghosts on 'distemper'd imagination' or 'the reciprocal pleasure of deluding and being deluded' or 'early errors of infancy and a motley mixture of the low and vulgar education' through nurses' stories and 'traditionary accounts' from places famous 'for their antiquity and decays' and 'half-penny bloody murder' pamphlets. But he also criticises the 'story of Madam Veal' and others produced 'from trick and design' and the use of names like Clarendon and Boyle to authenticate accounts 'till at last we are convinc'd by a whole conclave of ghosts met in the works of Glanvil and Moreton'. He concludes with the watchman story, this time presented as between 'the late Dr Fowler, Bp of Gloucester', a 'zealous defender of ghosts', and 'the late Mr Justice Powell ... somewhat sceptical and distrustful of their being' ${ }^{40}$ This version of the story ends with the words 'The Judge had no sooner ended, but the Bishop disappear'd.' In this format, as the story of a bishop and a judge (often not named), this anecdote became a standard sceptical tale, with its own slightly supernatural ending implied by the sudden disappearance of the bishop! ${ }^{41}$

\section{$1750-1789$}

Apart from Defoe and the 1720s reprints, the period between 1706 and 1749 seems to mark a lull in publications, perhaps reflecting an increased scepticism. However, the following decades saw a distinct revival (in

\footnotetext{
${ }^{39}$ G. L'E. Turner, 'Baker, Henry (1698-1774)', Oxford Dictionary of National Biography, 1120; id., 'Henry Baker F.R.S', Notes and Records of the Royal Society 28 (1974), 53-80 at 57 for Baker's editorship until January 1733.

${ }^{40}$ Sir John Powell (1645-1713) was the judge in the 1712 Jane Wenham trial who recommended her pardon after the jury convicted her of witchcraft against his guidance: see P.J. Guskin, 'The Context of Witchcraft', Eighteenth-Century Studies, 15 (1981), 48-71; Peter Elmer (ed.), English Witchcraft 1560-1736 Volume 5 The Later English Trial Pamphlets (2003); Mark Knights, The Devil in Disguise (Oxford, 2011), 193-240.

${ }^{41}$ The story is not in John Brand, Observations on Popular Antiquities (1777), but is in the 1813 edition (ed. H. Ellis), vol. 2, 428, and in various early nineteenth-century joke collections and magazines, starting with New Joe Miller or the Tickler (1802), 28.
} 
addition to the $1752 / 4$ versions of $A$ View). In 1750, A View of Human Nature or Select Histories (printed for S. Birt in Ave-Mary-Lane, 320 pages of duodecimo) promised, among many other 'remarkable instances of divine providence', chapters on 'magicians, witches, wizards etc', 'apparitions of persons deceased' and 'apparitions of demons and spirits'. But the volume, largely derived on its own admission from Nathaniel Wanley's Wonders of the Little World (1677, then an abridged 1704 edition) contains no stories post-1600 (like Wanley), except for one account from Walton's Lives and the 'well-attested account' of Mrs Veal.

The pace quickened in 1758, with the anonymous publication in London of Life after Death, or the History of Apparitions, Ghosts, Spirits or Spectres. Consisting of variety of true stories, attested by people of undoubted veracity, a 70-page octavo volume with no publisher given, but reprinted, with identical text and layout, in 1762 as The History of Apparitions, Ghosts, Spirits or Spectres ... by a Clergyman by J. Simpson at the Shakespeare's Head. ${ }^{42}$ One or possibly two further editions followed between c.1775 and 1787 as Life after Death or a Descriptive Account of the Most Remarkable Apparitions, Spirits, Ghosts or Spectres of Persons that have really Appeared after their Decease. The 1758 edition begins with an introduction similar to the 1752 View, ending with the same Addisonian passage, but contains a different range of stories, giving sources for each, including a number from 'Moretus' (i.e. Moreton) as well as Beaumont, Turner, Wanley and others. It also concludes with the identical sceptical conclusion that appeared as a footnote at the end of the 1752 View, culminating with the Fowler anecdote.

In $1759 \mathrm{H}$ Woodgate and Samuel Brooks at the Golden Ball in Paternoster Row published a 116-page duodecimo entitled $A n$ Authentick and Complete History of Witches and Apparitions. Shewing the reality of their existence in upwards of twenty-five curious and uncommon relations. The other books advertised at the front (a Christian's Memorandum Book, Bibles, prayer books and spelling and school books) suggest this was aimed at a broad market, though no price is given. The entire volume is a selection, without attribution, from Saducismus, with no preface or commentary, merely the documented accounts of specific

\footnotetext{
${ }^{42}$ Handley, Visions, cites it as an example of a short collection of ghost stories penned by 'conformist clergy' to grab the attention of readers ( 244 n. 91).
} 
cases. The following year Woodgate and Brooks were among the six Paternoster Row publishers (led by Charles Hitch, the former partner and son-in-law of Bettesworth) who published a 154-page duodecimo History of Witches and Wizards supposedly written by 'W.P.'. The brief preface asserts that only atheists would deny the reality of witchcraft and promises accounts from 'very approved and credible historians' whose names are listed, so giving the essentials of 'several large volumes' in 'a small manual and for a small price'. But despite the title page's claim that the stories were collected from 'Bishop Hall, Bishop Morton, Sir Matthew Hale' and so on, they are rather ineptly lifted, without attribution, from Saducismus, Crouch's Wonderful Prodigies, Wanley's Wonders and, in particular, from Baxter (nine of the twenty-four chapters).

In 1770, two further titles were published, both by J. Evans of Paternoster Row, each 304 pages in octavo and costing 3s sewed. They differed solely in the opening words of the title, the first being Evidences of the Kingdom of Darkness and the second The Compleat Wizzard; presumably the publisher saw different audiences being attracted to the alternative titles. Both promised 'a collection of authentic and entertaining narratives of the real existence and appearance of ghosts, demons, and spectres, together with several wonderful instances of the effects of witchcraft, to which is prefixed an account of haunted houses and subjoined a Treatise of the Effects of Magic'. In practice, after a short preface defending the beliefs of 'our grave ancestors' against supposedly enlightened modern infidels, the text merely reprints stories from Saducismus and Aubrey, except for a chapter on 'the possessed, or the demoniac of Surrey [sic]', taken from one of the 1697-8 pamphlets regarding Richard Dugdale from Surey in Lancashire (214-32). ${ }^{43}$ Much of the same material was again recycled in The History of Witches, Ghosts and Highland Seers (undated, 3s, c. 280 pages) published by Robert Taylor in Berwick (active 1753-1781d). ${ }^{44}$ Taylor was not noted for chapbook or similar publications, publishing a six-volume edition of Molière as well as a large cookbook. The title page promised 'many wonderful well-attested relations of supernatural appearances, not published

\footnotetext{
${ }^{43}$ Perhaps as reproduced in Boulton, Compleat History, II: 166-242. See Jonathan Westaway and Richard D. Harrison, "'The Surey Demoniack"', Studies in Church History, 32 (1996), 263-82.

${ }^{44}$ Taylor's will proved 23 May 1781 is TNA PROB $11 / 1078 / 22$.
} 
before in any similar collection, designed for the conviction of the unbeliever, and the amusement of the curious'. It was taken largely from Saducismus and Aubrey again (though with more cutting to make this less apparent), together with Turner and Defoe, plus the occasional recent account, such as the apparition seen by Colonel Gardiner from Philip Doddridge's 1747 account of his conversion (79-80). ${ }^{45}$ The brief preface attacked 'this age of general debauchery, extravagance and dissipation', in which 'profligate men' laugh 'at a future state, at the stories of spirits and invisible beings' as 'the inventions of enthusiasm and a crazy disordered imagination', and hoped the book would bring 'wavering people' to believe in a future state and make 'the deists, freethinkers, and infidel rakes read and tremble'.

Finally, in 1784, a 48-page pamphlet appeared (costing 6d) entitled Wonderful Relations, promising a 'serious inquiry' into the survival of the soul after death to 'come again and revisit its friends' with God's permission 'fully confirmed in this edition by twelve wonderful, yet well attested relations of apparitions, dreams etc ... extracted from the works of the learned Mr Flavel, Dr Moore, Mr Baxter and others'. The 20-page second half contains 11 cases, the final one being a modern one from St Ives in Cornwall in 1764, although one chapter has a postscript noting a similar occurrence in a newspaper case reported in November 1783. The opening stories are taken from John Flavel's Treatise on the Soul of Man (1685), but the others all appear in Beaumont, rather than More or Baxter (though Beaumont had attributed one to Baxter). The author is merely given as 'J.W. author of the Evening Conference between Christ and Nicodemus', but this identifies him as James Wakelin, who is also one of those selling the volume, 'printed by H. Trapp, no. 1 Paternoster Row, and sold by J. Wakelin No 3 King's Head Court, Shoe Lane and J. Dodd at the Bible in West Street, Seven Dials'. Trapp had also published the first half of the book separately for Wakelin in 1783 as A Serious Enquiry (price 4d), so presumably they judged its arguments would sell better with 'wonderful relations' added. A 'fourth edition' of 1787 was printed by Trapp for Wakelin and two booksellers in Halifax. Wakelin was a former minor actor at the Haymarket Theatre, who opened a bookshop in Shoe Lane, publishing mostly short moral and religious

\footnotetext{
${ }^{45}$ Barry, Raising Spirits, 63-5.
} 
tracts advocating the need for 'new birth' through Christ and life after death. ${ }^{46}$

With Wakelin, we move into the sphere of evangelical publishing. The role played by the supernatural in the evangelical revival, and especially in the publishing activity of John Wesley, his Arminian Magazine and other Methodist memoirs and tracts, has been well-studied, and I will not consider it here (except in the cases of Simpson and Tregortha). ${ }^{47}$ However, there can be little doubt that evangelicalism played a decisive part in creating not only a new demand for providential stories but also a new supply of such stories. The classic case is A Relation of Apparitions of Spirits in the Principality of Wales (1780) by the independent minister Edmund Jones. ${ }^{48}$ But no English evangelical appears to have published any anthology before 1791 .

\section{AfTER 1789}

Three main developments occurred after the French Revolution. The evangelical revival generated ever more publications (especially provincial), a group of occult practitioners began to publish, and the Gothic craze in fiction generated serials and chapbooks which included supernatural tales of various kinds, including supposedly factual ones. At the same time, a much more intensive campaign of publishing by sceptics seeking to debunk such experiences as either fraudulent or the result of mental delusion not only led to more intense debate about such stories

\footnotetext{
${ }^{46}$ J. Milling, 'Baker, Sarah (1736/7-1816)', Oxford Dictionary of National Biography, 49699: Baker was his daughter.

${ }^{47}$ Owen Davies, 'Methodism, the Clergy, and the Popular Belief in Witchoraft and Magic', History, 82 (1997), 252-65; id., 'Wesley's Invisible World', in Robert Webster (ed.), Perfecting Perfection (Cambridge, 2016), 147-72; Handley, Visions, 148-53; Henry Rack, 'Charles Wesley and the Supernatural', Bulletin of the John Rylands University Library of Manchester, 88: 2 (2006), 59-79; id., 'A Man of Reason and Religion? John Wesley and the Enlightenment', Wesley and Methodist Studies, 1 (2009), 2-17; Robert Webster, 'Seeing Salvation: The Place of Dreams and Visions in John Wesley's Arminian Magazine', Studies in Church History, 41 (2005), 376-88; id., Methodism and the Miraculous (Lexington, KY, 2013).

${ }^{48}$ A modernised edition is John Harvey (ed.), The Appearance of Evil: Apparitions of Spirits in Wales (Cardiff, 2003) but see Geraint H. Jenkins, 'Jones, Edmund (1702-1793)', Oxford Dictionary of National Biography, 61968; Barry, Raising Spirits, 67-70; Adam N. Coward, 'Edmund Jones and the Pwcca'r Trwyn', Folklore, 126 (2015), 177-95.
} 
but meant those wishing to publish such stories for establishment readers had to focus again on 'accredited stories', as in the Restoration period. I cannot look in detail at all the publications in this period (many are hard to identify and access, in the absence of a Short Title Catalogue or proper digital project for books after 1800), so I will only discuss some apparently representative cases, mostly up to 1825 .

Starting with evangelical publishing, the transition from reprinting classic accounts to new stories is well illustrated in A Discourse on Dreams and Night Visions (Macclesfield, 1791) by David Simpson, an evangelical Anglican clergyman who opened his own church in Macclesfield in 1779 and was a prolific author and hymn writer. Simpson, a farmer's son, believed he had heard a voice calling him to the ministry when a child, and his 144-page book devotes its first 60 pages to previously published cases, many from seventeenth-century authors, as well as one from the 1752 View, Doddridge on Gardiner and four cases from Thomas Wills' Spiritual Register (1784 and 1787), including what became a new staple, namely the prediction of the death of the libertine Thomas Lord Lyttleton in 1779 . He then records twenty pages of unpublished stories, 'all related to me by persons in whose veracity I can trust', before returning to some published examples, several from the Arminian Magazine, including Wesley's longest recorded narrative of that sort, regarding Elizabeth Hobson of Sunderland in 1768 (which Edmund Jones had also published). ${ }^{49}$

A more direct reflection of the impact of the French Revolution is found in the various works of 'Malcolm Macleod D.D.', printed and sold by J. Roach of Russel Court, Drury Lane. Roach specialised in works costing sixpence or a shilling, such as books of fortunes, jests, travels, stories, riddles and pocket companions, and Macleod's books, with Gothic typeface and illustrations on the front pages, selling for a shilling for about a hundred pages, were clearly aimed at a similar readership, offering numerous short tales, usually unattributed, though with some longer stories, several from Defoe. Macleod may be the Aberdeen graduate (though not recorded as a doctor of divinity) from Raasay, who became minister of the presbytery of Snizort and Uig in 1788 and died

\footnotetext{
${ }^{49}$ Mark Smith, 'Simpson, David (1745-1799)', Oxford Dictionary of National Biography, 25579 .
} 
there in $1832 .{ }^{50}$ In 1793 he published Macleod's History of Witches etc. The Majesty of Darkness Discovered: in a series of tremendous tales, mysterious, interesting and entertaining, of apparitions, witches, augurs, magicians, dreams, visions and revelations in confirmation of a future state (generally known thereafter as The Majesty of Darkness, e.g. in an 1804 New York edition). While some of these stories were from the standard sources, others were more recent (Including Gardiner and Lyttleton), and, uniquely, the minority of stories which refer to witches (as opposed to dreams or apparitions) do not reproduce cases from the witch trials, but rather two very lurid medieval stories and then two recent ones, namely an unnamed 'witch of Wigan' who was supposedly found as a hare in 1755 (71-2) and Mary Marshall, 'the wise woman of Worcester', who was reputed to be able to set the local mill turning for her corn by flying round it and had supposedly been seen taking off on her broom by Sir Thomas Lyttleton and other gentlemen who had gone to test her predictive skills at night (56-7). However, the book also contains a heavily biblical introduction, several references to Wesley and one to hearing the evangelical Toplady (author of 'Rock of Ages') and finally ends with a 'prophecy of Pedan' supposedly found in a Hebridean cave by $\mathrm{Dr}$ Johnson, which had predicted the French Revolution. (This seems to be a bizarre addition to the well-known prophecies of the seventeenth-century Covenanter Alexander Peden, including one of a French invasion of Scotland, which had no relation to a Hebridean cave or Dr Johnson!) This millenarian spirit of the 1790s is even clearer in Macleod's next book, The Mystery of Dreams Discovered (1794), again mixing familiar stories with modern ones (some from the newspapers) for the first fifty pages, then offering a 'New and Complete Dictionary of Dreams', before ending with 'sublime visions of Selina' from manuscripts found in the cabinet of the evangelical Selina Hastings, countess of Huntingdon, supposedly written by a late popular preacher in 1759 , which concludes 'let Freedom as in Albion reign in France' (81-7). Macleod included more medieval tales of witchcraft and magic (English as well as Scottish) in his Tales of Tiviotdale (1798), supposedly told by a monk of Melrose to Edward I. But he also published a work which takes him closer to the occult writers discussed in what follows, namely his The Key of Knowledge, or Universal Conjuror, Unfolding the Mysteries of the Occult

\footnotetext{
${ }^{50}$ H. Scott (ed.), Fasti Ecclesiae Scoticanae vol. 7 (Edinburgh, 1928), 179-80.
} 
Sciences, and being a Guide to the Temple of Wisdom (undated, but after 1794 as the title page refers to his first two books). Despite the title, this is a very different product, with no millenarianism or religious message, but a decidedly sceptical introduction casting the occult into a Gothic past, and inviting the reader to learn the techniques of practical magic, partly to avoid being deluded by conjurors and tricksters, although the author clearly believes in astrology and herbal charms. ${ }^{51}$ Readers who purchased the book hoping for similar material to his previous publications may not have appreciated the paragraph (41) where he states 'the author would now have proceeded to present his readers with a chapter or two on Apparitions, Witches and Dreams, but having anticipated himself in two treatises already published [titles given in the footnote]' he will instead treat other 'arts and sciences'! One wonders if this book was actually by Macleod at all.

The final religious title to be considered was both much more representative of the evangelical mainstream and much more influential, going through numerous variant editions in the first half of the nineteenth century. It was also a very substantial work, at over 400 pages of closely printed duodecimo, which effectively brought together in one compendium most of the classic stories from the seventeenth-century authors with a host of new eighteenth-century material, much of it from the Arminian Magazine. This was News from the Invisible World: or Interesting Anecdotes of the Dead. Containing a particular survey of the most remarkable and well-attested accounts of apparitions, ghosts, spectres, dreams and visions, with some valuable extracts from the works of the Rev. John Wesley, the Rev. David Simpson and others ... the whole forming a series of useful and necessary information for the support of our faith and practice (Burslem, undated, c. 1800). A standard preface defended the reality of the spirit world, though in cautious (largely biblical) terms, and promised extracts from the 'expensive and voluminous' works of the 'most learned and judicious authors' 'with all precision possible' but leaving the reader 'to judge for himself whether they are natural or miraculous events' (ii). The editor and publisher was a former Wesleyan lay preacher from Cornwall, John Tregortha (d.c. 1821), who had settled at Burslem near Stoke by 1796 as a printer and bookseller,

\footnotetext{
${ }^{51}$ For such books see: L. Schmidt, 'From Demon Possession to Magic Show', Church History, 67 (1998), 274-304; Michael Mangan, Performing Dark Arts (2007).
} 
publishing editions of religious classics such as Bunyan, his own complete family Bible with commentary, works of Methodist history and other texts defending the reality of divine providence, as well as chapbook publications like Mother Bunch's Closet Newly Broken Open and A History of Richard Whittington. The book had a complex publishing history, going through editions with the same core title but varied subtitles, usually with the same preface but then with the stories in varying order. Editions are recorded in 1808, 1812, 1813 and 1814 at Burslem, plus an undated 'new and improved edition' there, then (after his death and the bankruptcy of his son John junior in 1822) at Manchester in 1827, 1828 and 1835 . By the 1813 edition the reference to 'support of our faith and practice' had been dropped (but the Hobson story by Wesley was brought to the start), while the last Burslem and later editions modified the subtitle, offering instead 'a number of well attested facts; showing their power and influence on the affairs of mankind; with several extracts and original pieces from the writings of the best authors. The whole designed to prevent infidelity, show the state of separate spirits and evince the certainty of the world to come.' Then, at least by 1836, the title (and some of the content) was taken over by an otherwise unknown author called (from 1843 onwards) 'T. Ottway'. In his first London edition, printed for Joseph Smith at $3 \mathrm{~s}$ in $24 \mathrm{mo}$, it had the slightly amended title The Spectre, or News from the Invisible World, a collection of remarkable narratives on the certainty of supernatural visitations from the dead to the living etc; impartially compiled from the works of Baxter, Wesley, Simpson and other authors of indisputable veracity. But by 1840 'The Spectre' had been dropped, and, with some editions reprinting Tregortha's preface, readers could reasonably have assumed they were reading the same book, but they were not, as it contained a different selection of stories, which also varied between the 1840 and 1843 editions, but then remained constant in later editions (some in London, some in Halifax) in 1844, 1848, 1853,1860 and finally in 1870 (when the author's name also changed to 'T. Charley'!). ${ }^{52}$

Returning to the 1790s, we can now explore the second occult/ Gothic stream of publications, notably those associated with Henry and Ann Lemoine. Henry Lemoine (1756-1812), a Spitalfields-born author

\footnotetext{
${ }^{52}$ F.F.B., 'John Tregortha', Proceedings of Wesley Historical Society, 22:1 (1915), 15-20; Barry, Raising Spirits, 71; Davies, 'Wesley's Invisible World', 159-60.
} 
and bookseller who operated on the edges of the bookselling trade, married Ann Swires in 1786, and in 1791 he published Visits from the World of the Spirits or Interesting Anecdotes of the Dead, a 302-page duodecimo (reprinted in 1830, and abridged as a Glasgow chapbook in 1845), largely based on the 1770 revised edition of Defoe, but with a new preface and some new stories. ${ }^{53}$ The same year he began The Conjurors Magazine. A 'memoir' of Henry noted that the magazine 'lasted only three years. During this time he brought out a collection of apparitional histories prefaced by an ingenious argument prepared to convince the world of the reality of "the visits from the world of the spirits", the title of the book, but beyond that he did little more but write over again Baxter, Moreton, Glanvill, Webster, Dr Henry More, and repeat his own stories and others from the Arminian Magazine, one of the most emphatical of which is entitled "Death in the Pot".' By 'repeating his own stories' the memoirist probably means that Lamoine printed the same stories in The Conjurors Magazine, each monthly issue containing near the end a section on 'apparitions, dreams etc', the very first story in August 1791 (27) being indeed 'Death in the Pot'. ${ }^{54}$ When he lost control of this magazine (renamed The Astrologers Magazine) in 1793, he started The New Wonderful Magazine, and Marvellous Chronicle: or, New Weekly Entertainer. A work recording authentic accounts of the most extraordinary productions, events, and occurrences, in providence, nature, and art in January 1793, costing 6d weekly, which ran for sixty issues with almost 2000 pages (also available in a five-volume set). ${ }^{55}$ The magazine prompted a sceptical publication by the Dublin playwright Walley Chamberlain Oulton, entitled The Wonderful Storyteller or New Pocket Book of Agreeable Entertainment, consisting entirely of a great variety of valuable articles not included in the Wonderful Magazine ... dedicated to the numerous purchasers of the Wonderful Magazine and the public

\footnotetext{
${ }^{53}$ Baine, 'Daniel Defoe', 336.

${ }^{54}$ Memoirs of Mr Henry Lemoine', The New Wonderful Museum and Extraordinary Magazine (1807), 2218-40; David Goldthorpe, 'Lemoine, Henry (1756-1812)', Oxford Dictionary of National Biography, 16430; Iain McCalman, 'New Jerusalems' in Knud Hakonssen (ed.), Enlightenment and Religion (Cambridge 1996), 312-35.

${ }^{55}$ This took its full title from an earlier Wonderful Magazine which had started in September 1764, and apparently ran until 1766, although only issues to January 1765 are available.
} 
at large (1795). It was published by the same booksellers, C. Johnson and A. Hogg in Paternoster Row, who published the magazine it satirised, but all Oulton's 'wonderful stories' turned out to be frauds or delusions. ${ }^{56}$

In 1794-5 some injudicious loans rendered Henry Lemoine bankrupt, and he separated from Ann, pursuing a chequered career as an itinerant bookseller and hackwriter, but Ann, who became the major Gothic chapbook publisher, adopted the stories Henry had collected, and she and other chapbook sellers produced a series of 48-page texts based on them. In 1799, J. Barker in Great Russell Street Covent Garden (publisher of the two late editions of Nocturnal Revels) produced Apparitions, Supernatural Occurrences demonstrative of the Soul's Immortality for one shilling, and the next year Ann Lemoine published (for 6d) New Lights from the World of Darkness, or the Midnight Messenger, with Solemn Signals from the World of Spirits ... The whole forming a constellation of horror!!, also sold by T. Hurst in Paternoster Row. Several of the stories in New Lights appear to be Gothic short fictions, not factual accounts. In 1802-4, Hurst ran The Marvellous Magazine and Compendium of Prodigies, which serialised short Gothic novels, while Ann published Tales of Terror! Or More Ghosts, forming a Complete Phantasmagoria, a chapbook of fictional tales, in 1802 and then The Tell-Tale or Universal Museum (1803-5), which serialised Gothic chapbooks. ${ }^{57}$ Tegg and Castleman were also leading publishers of such Gothic 'blue books', and in 1803 they produced Tales of Superstition, or Relations of Apparitions, a sixpenny 48-page chapbook, apparently a reprint from another magazine (as it includes a title page for The New Conjurors Museum and Magical Magazine no. 6), with a standard repertoire of apparition stories. ${ }^{58}$ Finally, in 1810, T. and R. Hughes of Ludgate Street published another such chapbook, Fair and Fatal Warnings or Visits from the World of Spirits, further recycling materials from the Lemoine collections.

\footnotetext{
${ }^{56}$ Sidney Lee, 'Oulton, Walley Chamberlain ( $f$ l. 1783-1820)', rev. Peter Thomson, Oxford Dictionary of National Biography, 20952.

${ }^{57}$ Potter, History, 44-9; id., Literary Mushrooms: Tales of Terror and Horror from the Gothic Chapbooks, 1800-1830 (Crestline, CA, 2009).

${ }^{58}$ See http://hdl.loc.gov/loc.rbc/serial.50689.2 for the first issue, wrongly estimated as 1806.
} 
Henry Lemoine was on the edge of the occult revival of this period, led in publishing terms by astrologers such as Ebenezer Sibly in the 1790s and then 'Raphael' in the 1820s. Their own books reproduced some such stories, and Raphael also included some Gothic fiction in his publications, which played heavily on a Gothic sense of horror. ${ }^{59}$ Sibly's 1790s publishers, Champante and Whitrow of Jewry-Street, were responsible for another (undated) chapbook The Midnight Monitor, or Solemn Warnings from the Invisible World, being Authentic Narratives of the Wonderful Imposition of Divine Providence. Similar stories (plus some new Irish ones) also appeared, alongside essays on animal magnetism and Behmenist visions, in a short-lived Dublin magazine of 1809, The Supernatural Magazine.

It was in reaction to the swelling tide of such publications, and mounting establishment fears regarding the credulity and instability of popular opinion, that the post-1789 period also saw many publications seeking to discredit such tales. Some focused on the education of (middle-class) children, such as Mary Weightman's The Friendly Monitor or Dialogues for Youth against the Fear of Ghosts and other Irrational Apprebensions (1791), reissued in 1796 with a new title page (but otherwise identical) as The Death-Watch: Dialogues upon Spirits ... by a Country Clergyman! ${ }^{60}$ Another piece for children (or their anxious parents) from the Newbery Press was Richard Johnson's False Alarms, or the Mischievous Doctrine of Ghosts and Apparitions, of Spectres and Hobgoblins, Exploded from the Minds of Every Miss and Master (1796, then 1799, 1802, 1805 and 1807). Others were aimed at chapbook readers: the debunking of several apparition stories in James Lackington's 1791 memoirs formed the centrepiece of An Account of Some Imaginary Apparitions the Effect of Fear or Frand (Dunbar, n.d.). A larger and more sophisticated collection in the same vein is Joseph Taylor's Apparitions, or the Mystery of Ghosts, Hobgoblins and Haunted Houses Developed (1815), published by Lackington, Allen and Co. Taylor explains that until the age of 23 he had a 'dread of phantoms' due to 'having read many books in favour of ghosts and spectral appearances' in

\footnotetext{
${ }^{59}$ Barry, Raising Spirits, 80-95.

${ }^{60}$ Celestina Wroth, "“To Root the Old Woman out of Our Minds": women educationists and plebeian culture in late-eighteenth-century Britain', Eighteenth-Century Life, 30:2 (spring 2006), 48-73; Handley, Visions, 192-7.
} 
early life (v) but, when living in a supposedly haunted country mansion, learnt the need to overcome such fears through a thorough investigation. After an opening essay he then offers some 220 pages of stories where apparitions turn out to be false, including, of course, the Fowler/ Powell anecdote from the 1732 article (116-18).

From about this time, the focus of sceptical writings began to move towards medicalised explanations, most famously in John Ferriar's An Essay towards a Theory of Apparitions (1813, though based on his paper given in Manchester in 1790), John Alderson's An Essay on Apparitions (1823) and Samuel Hibbert's Sketches of the Philosophy of Apparitions (1824). Ferriar refers directly to some of the stories we have been examining: he quotes in full an example from Bovet (87-93, but does not then explain it), a Salem case from Mather's Wonders (34-7) and remarks sarcastically that 'there is ghostly authority for the division of a goblin equal to most of Glanvill's histories' (36) but only discusses in detail Beaumont's account of his own experiences with spirits (67-75, 103). ${ }^{61}$ Significantly, John Cumming (a nom de plume for William Andrew Mitchell, a newspaper editor in Newcastle-on-Tyne, according to his obituary in his Tyne Mercury of 25 November 1845), in An Essay on Capacity and Genius ... Also Enquiry into the Nature of Ghosts and other Appearances Supposed to be Supernatural (1820), which contains a long appendix 'with some authenticated relations of apparitions on which readers may exercise judgements' (441-537), notes (465) the 'surprise of readers' that Ferriar only relates 3 or 4 stories of apparitions. He himself tackles many more, including standard cases from 'Glanvil', Aubrey and 'Moreton' (479-497), attempting to explain each through imagination or fraud. Hibbert also scatters brief references to stories from Baxter, Turner, Glanvill, Aubrey, Bovet and Beaumont across his text (113-15, 167-9, 226-9), often suggesting drinking problems as an explanation, but pays more attention to Lee's letter to Fowler (as reproduced in Beaumont) as 'told better than most ghost stories' and 'one of the most interesting ghost stories on record' and having 'no reasonable doubt' of the authenticity of the narrative, but questioning whether we can trust 'a physician of olden time' in his judgement of the girl's health

\footnotetext{
${ }^{61}$ John Ferriar, 'Of Popular Illusions and Particularly of Medical Demonology', Memoirs of the Literary and Philosophical Society of Manchester, III (1790), 31-116; K. A. Webb, 'Ferriar, John (1761-1815)' Oxford Dictionary of National Biography, 9368.
} 
(169-73) and then to Doddridge's account of Gardiner (193-7) and Walton's account of Donne (353-5). James Forsyth, a Surrey surgeon and medical/scientific author, also refers to cases from More, Glanvill, Aubrey and Beaumont in his Demonologia or Natural Knowledge Revealed, being an Expose of Ancient and Modern Superstitious Credulity and Imposture (1827), but his chapter on apparitions (178ff) is plagiarised from Hibbert. William Newnham, another Surrey medical practitioner, also discusses some 'popular histories', including the Lyttleton case, in chapter 16 of his Essay on Superstition (1830). ${ }^{62}$

The final category of publications to be considered is a series of commercial publications from the 1820 s, clearly aimed at educated readerships who would be aware of the sceptical arguments of men like Ferriar but were still attracted to supernatural tales. The first is Accredited Ghost Stories collected by T.M. Jarvis esq. (1823, 6s), published by J. Andrews in New Bond Street. Jarvis is otherwise unknown, so it may be a nom de plume. After an introduction arguing for the value of such stories against atheism, given the uncertain evidence on both sides, and ending as ever with Addison, this offers 27 cases across 220 pages, most of them the standards from our seventeenth-century authors, plus more recent cases such as Veal, Wesley's account of the Epworth rectory disturbances, and apparitions mentioned in Boswell's Life of Johnson. A sceptical reviewer in the British Critic welcomed that his 'relations are free for the most part from ... visionary improprieties and impertinences', avoiding such 'species of accredited idology' as the drummer of Tedworth, and he praised a few stories, reprinting one in full. But he considers 27 'a scanty list it must be confessed for a period of more than three centuries', when readers could think of many more as well accredited 'at one sitting, round a blazing winter's hearth'. He then offers an essentially aesthetic judgement: 'A ghost story is like a pun. It must either be extremely good, or in the other full extremity of badness. Here, as in poetry, mediocrity is the only quality which cannot be tolerated.' In doing so, one might argue the reviewer is following the logic of Jarvis's own decision to call these 'stories', not accounts or narratives, appealing, surely, to the growing market for overtly fictional 'ghost stories'. ${ }^{63}$

\footnotetext{
${ }^{62}$ P. W. J. Bartrip, 'Newnham, William (1790-1865)', Oxford Dictionary of National Biography, 20030.

${ }^{63}$ British Critic, 20 (1823), 588-93.
} 
The same borderline is trodden the following year by Richard Warner (1763-1857), in the second volume of his Illustrations, Critical, Historical, Biographical and Miscellaneous of Novels by the Author of Waverley, that is Sir Walter Scott (whose own mixture of Romantic fascination and enlightened scepticism towards the supernatural has been much analysed). ${ }^{64}$ Warner was a non-evangelical Anglican clergyman and antiquarian, based from 1794 in Bath, who published extensively, but 'his works were commercial rather than scholarly'; ${ }^{65}$ his three-volume work was published by six Paternoster Row booksellers, including Hurst (and Longman). Warner notes both older sources such as Dee, Bovet and 'solemn Aubrey', as well as Jarvis's recent book (which Scott owned). He offers an apparently sceptical judgement (178-9n) on 'how much the popular superstitions of every country are tinged with the prevailing complexion of its national character. In England, where people are of a gloomy or sober cast, the stories of apparitions are, for the most part, of a grave and consistent description: not so, however, with our lively neighbours the French'. Yet Warner then proceeds to select a series of accounts 'as carrying with them that impress of authenticity, which is generally deemed sufficient to establish the truth of any narration', especially where names are given (186). He then discusses the Villiers case (186-94, citing Clarendon, but also the 1729 edition of Defoe), the Lee letter to Fowler from Beaumont (194-7, but as discussed by Hibbert) and a case from Jarvis (205-21), as well as giving two contemporary cases known to him (221-3).

The following year saw the final publication to be considered here, namely Signs before Death and Authenticated Apparitions: in one hundred narratives collected by Horace Welby (1825, cost 6s, published by W. Simpkin and R. Marshall of Stationers Hall Court; an 1874 edition has a different introduction and amended selection of stories). Welby was the nom de plume of the prolific author and antiquary John Timbs (180175), whose more than 150 publications 'are compilations of interesting facts gathered from every conceivable quarter and relating to the most

\footnotetext{
${ }^{64}$ Coleman Parsons, Witchcraft and Demonology in Scott's Fiction (Edinburgh, 1964); Srdjan Smajic, 'The Trouble with Ghost-Seeing: Vision, Ideology, and Genre in the Victorian Ghost Story', English Literary History, 70 (2003), 1107-35.

${ }^{65}$ Michael Hicks, 'Warner, Richard (1763-1857)', Oxford Dictionary of National Biography, 28766.
} 
varied subjects'. ${ }^{66} \mathrm{He}$ began writing from 1820 as assistant to the radical Sir Richard Phillips, editor of the Monthly Magazine, and it is possible that his interest in this topic reflected Phillips' own unorthodox views on science, ${ }^{67}$ but it seems more likely that, like Nathaniel Crouch over a century before, Timbs was a commercial compiler of compendia, in his case clearly for the urban middle classes. His introduction, itself a compendium of arguments from previous prefaces, appeals for cautious belief against fashionable scepticism (including Ferriar and Hibbert), citing a long list of past writers (ending with the inevitable quote from Addison) and stressing that he is only offering 'a collection of facts, not of reasonings' and will 'leave the reader to form his own inferences and analogies' (vii). He then proceeds 'to illustrate, in a cursory manner, the principal authorities quoted in the following sheets', namely 'Beaumont's History of Apparitions, Glanvil's Saducissimus [sic] Triumphatus, Baxter's Visits from the World of Spirits, Sinclair's Invisible World etc'. He promises to extract 'their quintessence, by adapting their relations in language suitable to the taste of readers in the present day'. He criticises Beaumont and Glanvill for sometimes going beyond the bounds of credibility, preferring the 'more moderate and probable character' of Baxter and Sinclair (xiii-Xv). However, it is clear he has not actually used Baxter's 1691 book (which he wrongly states is 'for the most part compiled from Sinclair') but a volume published in 1791, that is to say Lemoine's Visits, while by Sinclair's Invisible World he actually meant the 1752 View of the Invisible World (see the story of the Abbey Vault he quotes on 236 and the 'Duel of the Two Brothers' at 301). In fact, Welby draws much more widely than these four authors, using Aubrey, Bovet, Defoe (Rogers, Scott and several of his unnamed stories, plus the Veal narrative, where he notes the attacks on Defoe's motives and authenticity 254-64), Boswell, Wesley from the Arminian Magazine (213-29, possibly via Southey's Life), plus other standards: 'Death in the Pot' is credited to 'World of Spirits 1796' (212). There are also a number of dated recent cases, including an apparition at Starcross in Devon in 1823 (40-4, from the New Monthly Magazine), "the extraordinary case of Anne Taylor of

\footnotetext{
${ }^{66}$ J. R. MacDonald, 'Timbs, John (1801-1875)', rev. Nilanjana Banerji, Oxford Dictionary of National Biography, 27460.

${ }^{67}$ Thomas Seccombe, 'Phillips, Sir Richard (1767-1840)', rev. M. Clare Loughlin-Chow, Oxford Dictionary of National Biography, 22167.
} 
Tiverton in 1814' (173-4), 'The Yatton Demoniac' [1789] 'with complete documents' (242-50), ${ }^{68}$ 'the apparition of Mr Barlow's huntsman in 1811' (278-9, from Gentleman's Magazine) and finally 'narration of the Sampford ghost in 1810 with affidavits and other documents etc' (301-12, from the pamphlets by the Rev. C. Colton, minister of Tiverton). At least one story, 'The Midnight Storm' (181-92), is clearly a Gothic fiction, set in a French chateau and ending with 'circumstances of unexampled horror'!

Welby's compendium, with its confused plundering from the tradition of publications studied here, epitomises the complex pattern of reuse and abuse of tales of the supernatural which this chapter has sought to uncover. A series of entrepreneurial publishers, mostly operating from Paternoster Row in London, experimented with anthologising these stories in varied combinations, usually in publications of $3 \mathrm{~s}$ to $6 \mathrm{~s}$ aimed at the middling sort and above, but sometimes in chapbook or serial format or in one-shilling compendia which might attract a lower-class readership. While the late-seventeenth-century texts provided the majority of stories, both Defoe's accounts and later stories published by evangelicals or in periodicals began to play a growing part from the 1770s onwards, while the popularity of Gothic fiction had some influence from the 1790s. Sceptical attacks on these stories clustered in the 1720-40 period and after 1790, with a rising tide after 1815 (not fully studied here), and they themselves were prone to retell useful anecdotes, like the bishopjudge story. Any attempt to analyse the stories themselves, or draw conclusions about their significance either in popular or educated culture, must begin by unravelling the publishing history by which they were transmitted and (not fully studied here) modified and retold, as well as re-interpreted.

${ }^{68}$ See Barry, Witchcraft, 206-55. 
Open Access This chapter is licensed under the terms of the Creative Commons Attribution 4.0 International License (http://creativecommons.org/licenses/ by $/ 4.0 /)$, which permits use, sharing, adaptation, distribution and reproduction in any medium or format, as long as you give appropriate credit to the original author(s) and the source, provide a link to the Creative Commons license and indicate if changes were made.

The images or other third party material in this chapter are included in the chapter's Creative Commons license, unless indicated otherwise in a credit line to the material. If material is not included in the chapter's Creative Commons license and your intended use is not permitted by statutory regulation or exceeds the permitted use, you will need to obtain permission directly from the copyright holder.

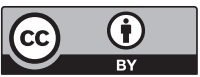

